\title{
Pohybový program pro jedince s rizikovými faktory kardiovaskulárních onemocnění
}

\section{Evaluation of the pioneer exercise training program for people with high risk of cardiovascular disease}

\author{
Michal Kumstát ${ }^{1}$, Robert Vysoký ${ }^{2}$, Iva Tomášková ${ }^{2}$, Iva Hrnčiříková1, Ondřej Smolka1 \\ ${ }^{1}$ Fakulta sportovních studií Masarykovy univerzity, Brno \\ ${ }^{2}$ Lékařská fakulta Masarykovy univerzity, Brno
}

\begin{abstract}
Abstrakt
Cílem sdělení je predstavit pilotní 3měsiční pohybový program zaměřený na III. a IV. fázi kardiovaskulární rehabilitace. Programu se zúčastnilo 6 osob (58土9 let) po akutním infarktu myokardu s nekomplikovaným průběhem, s provedenou revaskularizací myokardu. Pilotní projekt Fakulty sportovních studií, I. interní kardiologické kliniky Lékařské fakulty Masarykovy univerzity a rehabilitačního oddělení Fakultní nemocnice Brno v současnosti pokračuje druhým 3měsičním programem. Ukázala se zde potřeba vytvořit pevnějši návaznost na posthospitalizační rehabilitační fázi.
\end{abstract}

\begin{abstract}
The goal of the study was to introduce the 3-month fitness programme particularly focused on the III. and $I V$. stage of cardiovascular rehabilitation. Six persons ( $58 \pm 9$ years), all after acute myocardial infarction with an uncomplicated history who underwent myocardial revascularization, participated on the programm. It is important to note, that this mutual pilot project of the Faculty of Sports Studies, I. Internal cardiology clinics and Department of Rehabilitative Medicine in University hospital Brno, has indicated the need to establish a stronger continuity to the hospital rehabilitation programme. Contemporary, the pilot project is beeing succesfully followed by its second 3-month programme.
\end{abstract}

Klíčová slova: $\quad$ rehabilitace, kardiovaskulární onemocnění, pohybová aktivita.

Key words: $\quad$ rehabilitation, cardiovascular disease, physical activity.

\section{ÚVOD}

Kardiovaskulární onemocnění (dále KVO) se neustále drží na druhém místě v incidenci všech chorob, kterými je lidská populace v současné době ohrožována. Mortalita u těchto chorob setrvává i přes všechny moderní medicínské postupy na hodnotě okolo $50 \%$ (11).

Nedostatek pohybové aktivity je v naší zemi závažný problém, především $\mathrm{z}$ důvodu stále narůstajícího počtu obyvatel trpících následky sedavého životního stylu. Právě sedavý životní styl je jedním z významných faktorů ovlivňujících prevalenci kardiovaskulárních onemocnění (1).

Pohybová aktivita souvisí s aerobní zdatností, která významným způsobem ovlivňuje prognózu pacientů s KVO (5). Preventivní pohybové programy jsou v moderní medicíně nezastupitelným standardem moderní léčby pacientů s rizikovými faktory KVO. Českou kardiologickou společností (dále ČKS) byly vypracovány pokyny pro rehabilitaci pacientů s KVO, které popisují fáze kardiovaskulární rehabilitace, metodiku tréninku a další doporučení sekundárně-preventivní léčby (8).

Rehabilitace se dělí na 4 fáze. Cílem úvodní nemocniční fáze je připravit nemocného k návratu k běžným denním činnostem a předejít dekondici. Druhé fázi (tzv. posthospitalizační) s délkou trvání do 3 měsícu dominuje řízený ambulantní trénink. Druhá fáze může být organizována i jako individuální domácí trénink nebo lázeňská léčba. Třetí fázi (fáze stabilizace) charakterizuje důraz na upevnění změn životního stylu a vytrvalostní cvičení. Závěrečná fáze již předpokládá stabilizovaný zdravotní stav a pokračování v předchozích postupech (8).

Souhrnně můžeme konstatovat, že prospěch řízených pohybových programů u osob s rizikovými faktory KVO a s ICHS byl prokázán mnoha studiemi. Aerobní trénink pozitivně ovlivňuje 
toleranci zátěže, zvyšuje vrcholovou spotřebu kyslíku, př́íznivě ovlivňuje hemodynamické parametry a zvětšuje funkční kapacitu organismu tím, že snižuje tepovou frekvenci (dále TF) v klidu, snižuje tlak krve (dále TK), zvyšuje periferní žilní tonus a vede ke zlepšení kontraktility myokardu $(3,4,5,7,9,10)$.

Kromě aerobního tréninku, který je hlavním pohybovým prvkem prevence rozvoje rizikových faktorů KVO a ischemické choroby srdeční (dále ICHS) je velmi důležité zařazovat do cvičební jednotky i dynamická posilovací cvičení. U dolních končetin to jsou zejména dynamické stabilizátory kolenního kloubu, čímž předcházíme rozvoji patologií pohybového aparátu v daném segmentu (6).

Trénink kombinující prvky dynamické a statické zátěže je typickou součástí nemocniční fáze rehabilitace.V pozdějších fázích rehabilitace je rovněž úspěšně zařazován. Posilování svalstva horních a dolních končetin přirozeně odráží potřeby pacientů jak pro pracovní, tak rekreační pohybové aktivity. Jednostranně zaměřený trénink se snadno může stát nudným a pro pacienty nemotivujícím. Proto je vhodné prvky pohybové aktivity stř́ídat. (2)

\section{CÍL PRÁCE}

Cílem našeho sdělení je seznámit nejen odbornou veřejnost s uskutečněným pilotním pohybovým programem zaměřeným na III. a IV. fázi rehabilitace (dále RHB) u osob s rizikovými faktory KVO a jeho stávajícím pokračováním. Záměr vytvořit nezdravotnickou návaznost na rehabilitační péči je reakcí na chybějící program tohoto druhu v Brně.

Primárním smyslem projektu bylo umožnit pacientům zapojit se do odborně řízeného pohybového programu. Dílčím cílem bylo představit pacientům alternativy vhodných pohybových aktivit a rozšírit jejich nabídku.

\section{SOUBOR A METODIKA}

Pilotní pohybový program byl realizován na Fakultě sportovních studií v Brně v období 6. 4.29. 6. 2010. Programu se zúčastnilo 6 osob po akutním infarktu myokardu s nekomplikovaným průběhem, s provedenou revaskularizací myokardu. Průměrný věk $58 \pm 9$ let, ejekční frakce levé komory srdeční $58 \pm 7 \%$.

$Z$ rizikových faktorů se pacienti léčili s hypertenzí (n-2), diabetem mellitem II. typu (n-2), hyperlipoproteinémií (n-5). Pacienti neměli žádné kardiální komplikace, ani funkční pohybovou patologii, které by je výrazněji limitovaly v průběhu pohybového programu.

Dle kategorizace New York Heart Association spadali všichni do 1. funkční skupiny kardiaků, tedy bez zřetelného omezení fyzické aktivity dušností nebo stenokardiemi.

Všichni pacienti absolvovali ambulantní kombinovaný trénink (tj. aerobní a silový) v tzv. II. fázi kardiovaskulární rehabilitace dle Guidelines ČKS na Interní kardiologické klinice Fakultní nemocnice Brno (dále FN Brno) v letech 2008-2009.

$\mathrm{Na}$ Fakultě sportovních studií se uskutečnilo 12 tréninkových a 1 úvodní informativní jednotka. Cvičení probíhalo $1 \times t$ týdně v délce 90 min v tělocvičně nebo v posilovně. Součástí aerobní zóny posilovny byly stacionární, mechanicky brzděné rotopedy a magneticky brzděné veslařské trenažéry. Využíváno bylo jednoduché náčiní (overbally, fitbally, terabandy, stepy, bosu, malé půlkilové činky, atd.).

Tepová frekvence (dále TF) byla hlavním kontrolním indikátorem intenzity tělesné zátěže, přičemž doporučení tréninkové tepové frekvence (dále TTF) vycházelo $\mathrm{z}$ výsledků zátěžových testů pacientů. Kontrola tepové frekvence byla vždy provedena na začátku, opakovaně v průběhu cvičení a po jeho skončení (používány měřiče srdeční frekvence Polar S610i). Samožrejmostí bylo sledování dalších fyziologických odpovědí na zatížení (způsob dýchání, barva pokožky, známky únavy pocení, pohybový projev, atd.).

Pohybové jednotky lektoroval student postgraduálního studia společně se studenty bakalářského studia. Všichni byli proškoleni pro práci s automatickým defibrilátorem (Lifepeak CRplus Defibrilator, Medtronic).

Tabulka 1 shrnuje vybrané kardiovaskulární ukazatele tělesné zdatnosti osob vstupujících do pohybového programu. 
Tab. 1 Vybrané kardiovaskulární ukazatele zátěžového vyšetření cvičenců po absolvování ambulantního kombinovaného tréninku na Interní kardiologické klinice FN Brno

\begin{tabular}{|l|c|c|c|c|c|}
\hline & Ukončení RHB & $\mathrm{ANP}_{(1)}[\mathrm{TF} / \mathrm{min}]$ & $\mathrm{TF}_{\max }$ & $\mathrm{TF}_{\mathrm{klid}}$ & $\mathrm{VO}_{2 \max (2)}[\mathrm{ml} / \mathrm{kg}]$ \\
\hline cvičenec 1 & 9.9 .2008 & 122 & 142 & 75 & 23,8 \\
cvičenec 2 & 21.5 .2009 & 107 & 135 & 70 & 19,8 \\
cvičenec 3 & 16.10 .2008 & 111 & 120 & 70 & 19,2 \\
cvičenec 4 & 14.8 .2009 & 100 & 129 & 68 & 20,1 \\
cvičenec 5 & 27.1 .2010 & 81 & 91 & 56 & 15,6 \\
cvičenec 6 & 9.3 .2009 & 100 & 153 & 61 & 38,5 \\
\hline
\end{tabular}

(1) Anaerobní práh (2) Spotřeba kyslíku

Mezi ukončením řízené rehabilitace a nástupem do námi prezentovaného programu uplynula, s výjimkou jedné osoby, poměrně dlouhá doba (10 \pm 8 měsíců). Vzhledem $\mathrm{k}$ farmakologické léčbě jsou hraniční hodnoty $\mathrm{TF}_{\max }$ snížené (122 \pm 31 tepů/min). $\mathrm{TF}_{\max }$ je hodnotou nejvyšší tolerované srdeční frekvence (vrcholová - SF) dosažené při zátěžovém testu.

\section{HLAVNÍ CHARAKTERISTIKY POHYBOVÉHO PROGRAMU}

\section{Tréninkové jednotky}

Tréninkové jednotky byly rozděleny na úvodní, hlavní a závěrečnou část. Úvodní část (15-25 min) zahrnovala zahřátí modifikacemi chůze, klusu, běhu. Následovala vyrovnávací cvičení (uvolňovací, protahovací a posilovací prvky). Hlavní aerobní část (45-60 min) obsahovala trénink na rotopedech, skupinová a herní cvičení, cirkulující trénink (kruhový) a cvičení na velkých míčích. Cílem hlavní části byl rozvoj vytrvalostních schopností. Náplní závěrečné části (5-10 min) byla vyrovnávací cvičení s důrazem na namáhané svalové skupiny, relaxace a celkové uvolnění duševní tenze. Tréninkové jednotky doprovázela hudba.

\section{Tepová frekvence během cvičení}

TTF byla orientačně spočítána $\mathrm{z}$ individuálních hodnot tepové rezervy (dále $\left.{ }_{\mathrm{r}}^{\mathrm{TF}}{ }_{\mathrm{r}_{\mathrm{r}}} \mathrm{TF}=\mathrm{TF}_{\max }{ }_{\mathrm{k}} \mathrm{TF}\right]$ a klidové tepové frekvence ${ }_{k} T F$ stanovené před zátěžovým testem dle vzorce

$$
T T F=\left(T F_{\max }-{ }_{k} T F\right) \times(0,7-0,8)+{ }_{k} T F,
$$

kde hodnoty 0,7 a 0,8 (resp. 70 a 80 \% z rTF) představují hranici anaerobního prahu. Náš soubor tvořili zkušení pacienti s odstupem od ukončené rehabilitace, proto jsme zvolili tuto př́ínější kalkulaci (8).

Hodnoty $\mathrm{TF}_{\max }$ uvedené v tabulce 2 odráží průběžné sledování jedinců během tréninkových jednotek a záznamy měřičů srdeční frekvence.

Tab. 2 Srovnání TTF určených $\mathrm{z}$ výstupních vyšetření a průměrných dosahovaných hodnot $\mathrm{TF}_{\max } \mathrm{v}$ průběhu 3měsíčního cvičení

\begin{tabular}{|l|c|c|}
\hline & TTF $[\mathrm{tepy} / \mathrm{min}]$ & $\mathrm{TF}_{\max }[\mathrm{tepy} / \mathrm{min}]$ \\
\hline cvičenec 1 & $122-129$ & $120-130$ \\
cvičenec 2 & $116-122$ & $130-135$ \\
cvičenec 3 & $105-110$ & $135-140$ \\
cvičenec 4 & $111-117$ & $125-135$ \\
cvičenec 5 & $80-84$ & $110-115$ \\
cvičenec 6 & $125-135$ & $135-145$ \\
\hline
\end{tabular}


Obrázek 1 znázorňuje záznam intervalového tréninku na rotopedu. Zřejmý je rychlý pokles tepové frekvence (křivka), svědčící o dobrém funkčním stavu cvičence.

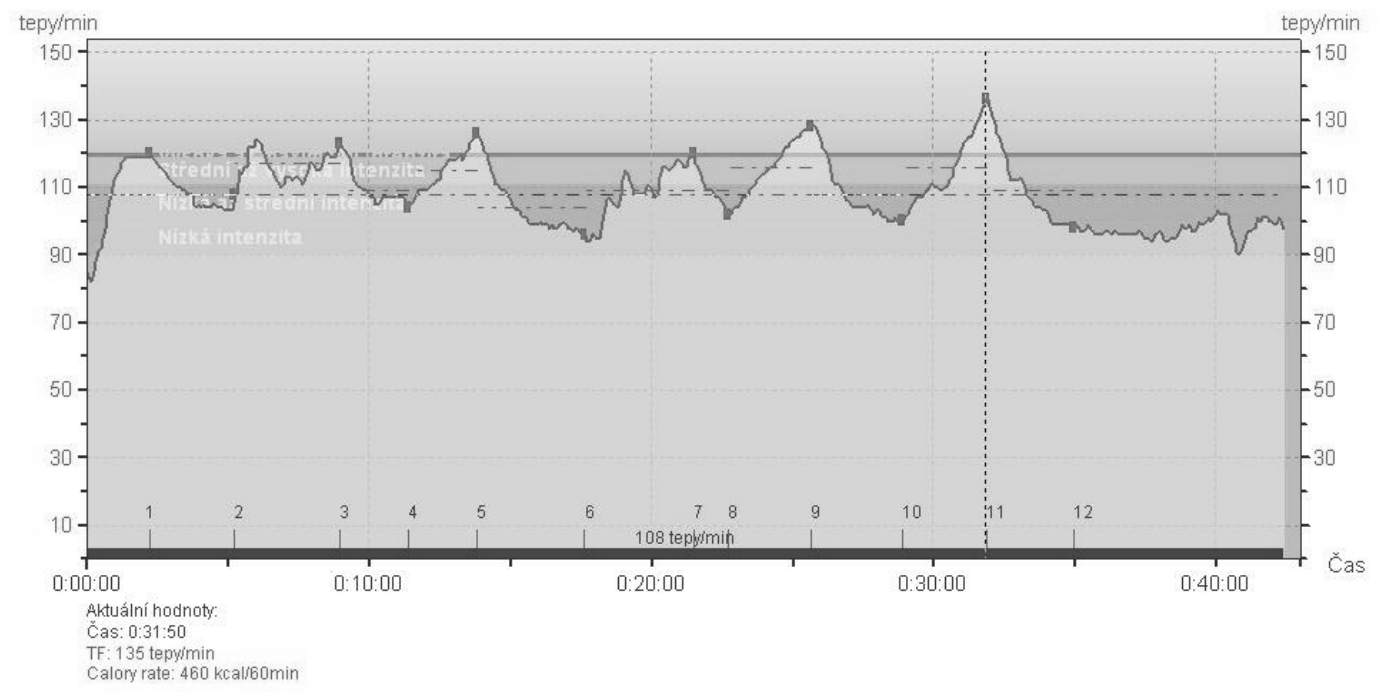

\begin{tabular}{|c|c|c|c|c|c|c|c|}
\hline Osoba & A. Š. & Datum & 11.5 .2010 & TF prüměr & 108 tepy/min & Limity 1 & $120-180$ \\
\hline Záznam & Intervalowy trénink na rotopedu & Čas & 18:55:10 & TF max & 136 tepy/min & Limity 2 & $105-110$ \\
\hline Druh aktivity & Pohybowy tréninkFSPS & Trváni & $0: 42: 29.1$ & & & & \\
\hline Poznámka & \multicolumn{3}{|c|}{ Intervalow trénink na rotopedu - $6^{*} 3 \mathrm{~min}$ stupñovanĕ s $2-3 \mathrm{~min}$ pausou } & Wýběr & \multicolumn{3}{|c|}{$0: 00: 00-0: 42: 25(0.42: 25.0)$} \\
\hline
\end{tabular}

Obr. 1 Př́klad grafického záznamu intervalového tréninku

\section{Př́íklady tréninkových jednotek}

Následující příklady stručně popisují formu a konkrétní podobu hlavních částí tréninkových jednotek.

Souvislé aerobní zatížení (45 min). Kontinuální trénink na rotopedu s variabilní intenzitou. Navazující úseky v délce 5 minut s proměnlivou, mírně rostoucí intenzitou. Individuální začátek 5-10 tepů pod hranicí TTF a cílová TF 5-10 tepů nad hranicí TTF (poslední úsek).

Intervalový trénink na veslařském trenažéru (45-50 $\mathbf{~ m i n ) . ~ T e n t o ~ t y p ~ t r e ́ n i n k u ~ b y l ~ z a r ̌ a z e n ~ p o ~ p r ̌ e d - ~}$ chozí konzultaci s fyzioterapeuty vedoucími řízenou rehabilitaci ve FN. Pacienti prošli tréninkem na veslařských trenažérech, byli technicky zdatní a uměli subjektivně posoudit odezvu na tento typ pohybového zatížení. Příklad tréninku s následující strukturou:

$[15 s+30 s+30 s+45 s+45 s+60 s+60 s+75 s+45 s+60 s+30 s+45 s+15 s] \times 2-3$ opakování

Kombinace zatížení (tučně) a pasivního odpočinku (kurzívou). Mezi jednotlivými sériemi pacienti absolvovali 5-10 min aktivního odpočinku na rotopedu (intenzita 50\% rTF). Intenzitu jednotlivých úseků pacienti upravovali zvýšením frekvence pohybu, popř. individuální modulací odporu.

Fartlek (40 min). Jde o souvislou tréninkovou metodu, která pracuje se změnami intenzity na základě okamžitých, neplánovaných, subjektivních pocitů. Tento typ tréninku byl zařazen na konec programu. Pacienti jej absolvovali na rotopedech, se kterými již měli dostatečnou zkušenost a zvládali autoregulaci odporu. Př́́klad: 4-5× [5 min stř́idavé úsilí s doporučenou TTF \pm 10 tepů/min $+2-3$ min lehké zatížení 50 \% rTF]

Kruhový trénink (40-50 min). Specifická metodicko-organizační forma je charakteristická postupným zapojováním vybraných svalových skupin při cvičení na stanovištích obvykle uspořádaných do kruhu. Volili jsme prvky odpovídající vyspělosti pacientů, koordinačně nenáročné a předem procvičené. Forma kruhového tréninku byla pro některé pacienty obtížnější, zejména po technické stránce. Proto bylo třeba dbát na správné provedení pohybů, pravidelné dýchání a zamezit chybným pohybovým stereotypům. Vždy bylo zařazeno jedno ukázkové cvičení, ve kterém si pacienti zkušebně prošli všemi prvky. 
Skupinové a štafetové hry. Nezastupitelnou roli v pohybu člověka kteréhokoliv věku má hra. Volili jsme skupinové a štafetové hry. Vzhledem ke zvýšenému emočnímu vypětí, přirozeně hru doprovázejícímu, jsme více sledovali doprovodné fyziologické odpovědi organismu.

\section{Doplňkové aktivity}

V současné době se na kardiovaskulární rehabilitaci nahlíží multidisciplinárně. Do každé tréninkové jednotky jsme zařazovali pravidelné řízené skupinové konzultace o výživě a dalších preventivních aspektech KVO. Jedna $\mathrm{z}$ konzultací byla věnována tělesnému složení s př́íkladem měření přístrojem InBody 230.

\section{Aktuální rysy programu}

V současnosti pokračuje na Fakultě sportovních studií druhý 3měsíční program. Po pozitivních zkušenostech z pilotního kurzu jsme zachovali formu a hlavní náplň cvičebních jednotek. Soubor tvoří opět pacienti FN Brno, kteří prošli II. fází kardiovaskulární rehabilitace. Stávajícího kursu se účastní 6 jedinců, z nichž velká část prošla pilotním programem. Evaluační dotazník po skončení prvního pilotního programu ukázal na spokojenost cvičenců s náplní a formou tréninkových jednotek. Hlavní charakteristiky programu jsme proto zachovali, opět s důrazem na variabilitu jednotlivých lekcí. Tréninková intenzita je monitorována jak měřiči srdeční frekvence (Polar), tak sledováním fyziologické odezvy na zátěž.

Navíc jsou v rámci kruhového tréninku zařazovány posilovací prvky na strojích. Důraz je kladen na správnost technického provedení a dýchání. Po každé tréninkové jednotce jsou opět zařazovány relaxační motivy doplněné o prvek masáží.

\section{DISKUSE}

Námi prezentovaný program nelze považovat za dostatečně kardiovaskulárně stimulující. Hlavním záměrem není dosáhnout zlepšení funkčních parametrů. Snažili jsme se poskytnout pacientům možnost řízeného kolektivního cvičebního programu. Evaluační šetření mezi pacienty po absolvování pilotního programu poukázalo na nedostačující návaznost na posthospitalizační RHB. Společně s nedostatkem vlastní pohybové aktivity tento jev pacienti řadili mezi nejsilnější motivační faktory pro zapojení se do programu. Navzdory faktu, že vycházíme ze statisticky nevýznamného vzorku, jde o významný fenomén.

Dalším $\mathrm{z}$ atributů tréninkového programu je fakt, že všichni pacienti bez komplikací krátkodobě překračovali $\mathrm{TF}_{\max }$ (stanovenou z výstupních zátěžových testů). I když je posuzování nárůstu funkčního stavu u každého rekonvalescenta v průběhu 1.-4. fáze kardiovaskulární rehabilitace bezpochyby individuální, naše pozorování naznačilo, že jejich funkční zdatnost se progresivně zlepšila i přes dlouhodobější absenci řízené pravidelné pohybové aktivity. Pozitivním zjištěním je také ustupující obava pacientů z proměnlivé intenzity zatížení, a s tím související individuálně zvýšená tolerance vyšších tepových hladin. Pacienti uvádí větší chut do pohybu, což je charakteristické pro skupinové cvičení. Strukturu pohybových jednotek jsme volili tak, aby co nejvíce rozvíjela pohybový fond pacientů. Současně jsme chtěli nabídnout pacientům možnosti pohybových aktivit, kterých se mohou bez obav účastnit.

\section{ZÁVĚR}

Po absolvování II. fáze RHB musí být pacient schopen samostatně trénovat a v následujících fázích by něměl být na řízeném programu dále závislý. Prezentovaný pohybový program a jeho pokračování potvrdily způsobilost jedinců $\mathrm{k}$ individuální modifikaci intenzity u širokého spektra aktivit.

Náš pilotní projekt nastartoval spolupráci mezi Fakultou sportovních studií a Fakultní nemocnicí Brno. Předmětem spolupráce jsou možnosti řízeného tréninkového programu spadajícího do III. a IV. fáze RHB pro osoby s rizikovými faktory KVO a s ICHS. Přestože jsou pacienti po ukončení II. fáze kardiovaskulární rehabilitace dostatečně edukováni po stránce tréninkových aktivit a dobře znají své limity a prrípadná rizika, program nabízí přínosnou alternativu pro ty, jejichž adherence k pohybovým aktivitám je snížená. 
První i navazující druhý pohybový program splňují cíle, pro něž byly vytvořeny. Rozšiřili jsme okruh pohybových aktivit, který může pacienty motivovat $\mathrm{k}$ pravidelnému tréninku. Ten je z prognostického hlediska u těchto jedinců klíčový.

\section{LITERATURA}

Beránková, L., Zvonař, M. Nedostatek pohybové aktivity - fenomén dnešní doby. Konference plná barev. Olomouc: Univerzita Palackého v Olomouci, Fakulta tělesné kultury, 2004, s. 10-14, 5 s. ISBN 80-244-0931-3.

Elbl L., Chaloupka V., Tomášková I. et al.: Vliv kombinovaného aerobního a silového tréninku na funkcí levé komory srdeční u nemocných po akutním infarktu myokardu. Vnitřní lékařství 2005. Vol. 51, No. 2, s. 190-197.

Elbl L., Chaloupka V., Tomášková I. et al.: Silový trénink u nemocných po akutním infarktu myokardu se sniženou ejekční frakcí levé komory. Vnitřní lékařství, 2005, Vol. 51, No. 1, s. 41-47.

Elbl L., Chaloupka V., Tomášková I. et al.: Remodelace levé komory srdeční u nemocných s akutním infarktem myokardu po absolvování ambulantního ř́zeného rehabilitačního programu. Cor et Vasa, 2005. Vol. 47, No. 4, s. 39-44.

Howley E. T., Franks B. D.: Health fitness instructor's handbook. $4^{\text {th }}$ edition, Human Kinetics, 2003, ISBN 0-7360-4210-5.

Hrazdira, L., Beránková, L., Sebera, M. Možnosti posilování hamstringů za pomoci speciální plošiny-první zkušenosti. Medicina Sportiva Bohemica et Slovaca, Praha: Česká společnost tělových. lékařství, 2006, 2, 2 s. ISSN 1210-5481.

Chaloupka V., Elbl L. Nehyba S. et al.: Rehabilitace po infarktu myokardu a revaskularizaci u starších nemocných. Vnitřní lékařství, 2005, Vol. 51, No. 4, s. 414-420.

Chaloupka V., Siegelová J., Špinarová L. et al.: Rehabilitace nemocných s kardiovaskulárním onemocněním. Doporučené postupy ČKS. Cor et Vasa, 2006, Vol. 48, No. suppl. 4, K127-K145.

Jančík J., Svačinová H., Dobšák P. et al.: Kombinovaný trénink u nemocných se systolickou dysfunkcí levé komory srdeční. Vnitřní lékařství, 2003, Vol. 49, No. 4, s. 280-284

Kavanagh T., Mertens D., Hamm L. et al.: Prediction of Long-Term Prognosis on 12169 Men Referred for Cardiac Rehabilitation. Circulation, 2002, Vol. 106, s. 666-671.

Petersen, S., Peto, V., Rayner M. et al.: European Cardiovascular disease statistics: London 2005. British Heart Foundation. 